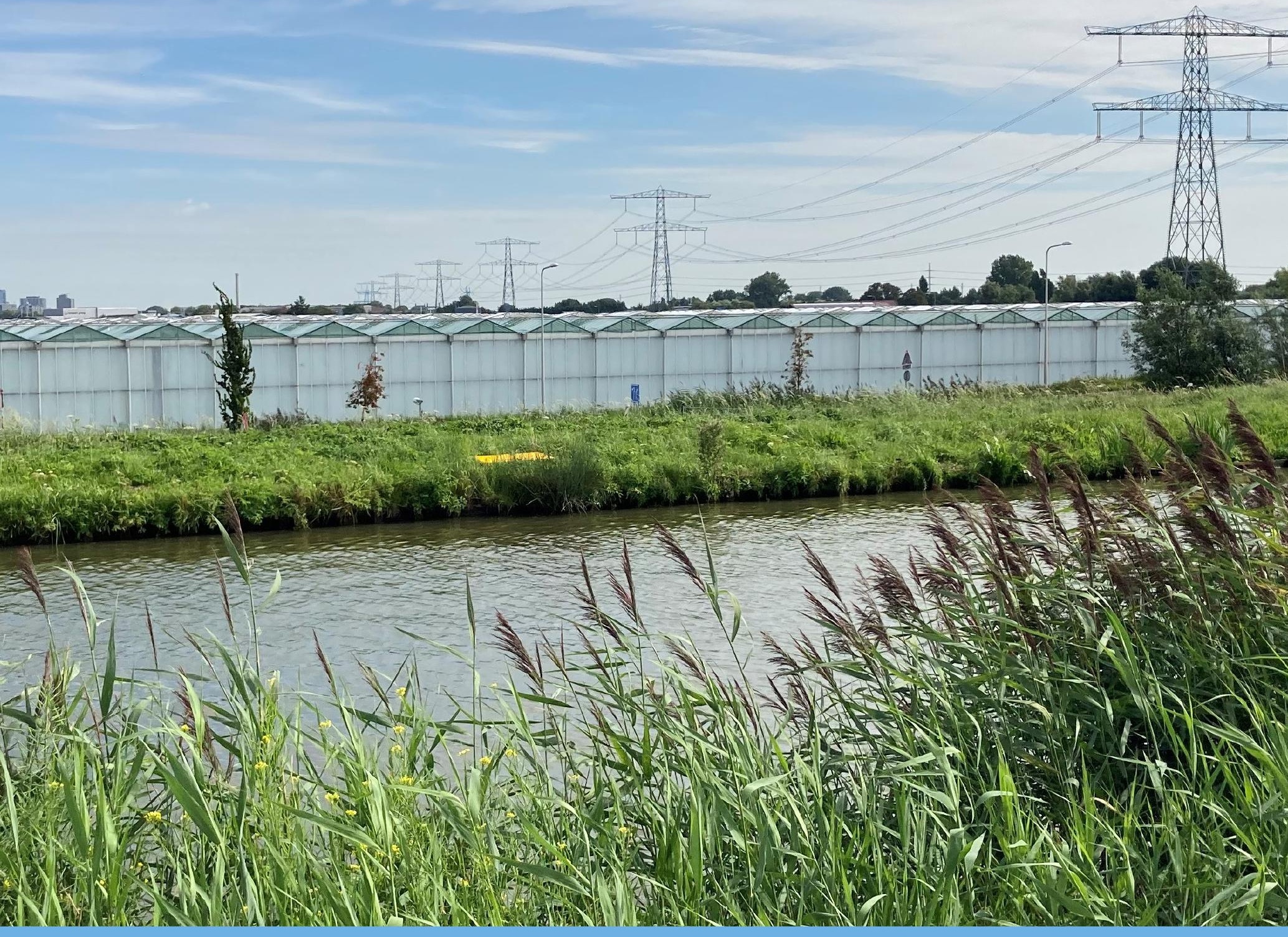

\title{
Bouwstenen voor evaluatie Smart Grid Westland
}

Pepijn Smit en Nico van der Velden 



\section{Bouwstenen voor evaluatie Smart Grid Westland}

Pepijn Smit en Nico van der Velden

Dit onderzoek is uitgevoerd door Wageningen Economic Research in opdracht van Westland Infra Netbeheer.

Wageningen Economic Research

Wageningen, september 2020

NOTA

2020-076 
Smit, P., N. van der Velden, 2020. Bouwstenen voor evaluatie Smart Grid Westland. Wageningen, Wageningen Economic Research, Nota 2020-076. 20 blz.; 0 fig.; 1 tab.; 5 ref.

Trefwoorden: Glastuinbouw, Westland, regio, energie, energievoorziening, netwerk.

Deze nota is gratis te downloaden op https://doi.org/10.18174/530706 of op www.wur.nl/economicresearch (onder Wageningen Economic Research publicaties).

(C) 2020 Wageningen Economic Research

Postbus 29703, 2502 LS Den Haag, T 07033583 30, E communications.ssg@wur.nl, www.wur.nl/economic-research. Wageningen Economic Research is onderdeel van Wageningen University \& Research.

\section{(cc) BY-NC}

Dit werk valt onder een Creative Commons Naamsvermelding-Niet Commercieel 4.0 Internationaallicentie.

(C) Wageningen Economic Research, onderdeel van Stichting Wageningen Research, 2020 De gebruiker mag het werk kopiëren, verspreiden en doorgeven en afgeleide werken maken. Materiaal van derden waarvan in het werk gebruik is gemaakt en waarop intellectuele eigendomsrechten berusten, mogen niet zonder voorafgaande toestemming van derden gebruikt worden. De gebruiker dient bij het werk de door de maker of de licentiegever aangegeven naam te vermelden, maar niet zodanig dat de indruk gewekt wordt dat zij daarmee instemmen met het werk van de gebruiker of het gebruik van het werk. De gebruiker mag het werk niet voor commerciële doeleinden gebruiken.

Wageningen Economic Research aanvaardt geen aansprakelijkheid voor eventuele schade voortvloeiend uit het gebruik van de resultaten van dit onderzoek of de toepassing van de adviezen.

Wageningen Economic Research is ISO 9001:2015 gecertificeerd.

Wageningen Economic Research Nota 2020-076 | Projectcode 2282200576

Foto omslag: P. Smit/Wageningen University \& Research 


\section{Inhoud}

\section{Samenvatting}

S.1 Smart Grid Westland biedt perspectief voor kostenbeheersing en verduurzaming 5

S.2 Effecten reiken voorbij de individuele klantrelatie $\quad 5$

S.3 Data, vraaggesprekken en analyse vormen bouwstenen voor evaluatie $\quad 5$

1 Inleiding

1.1 Smart Grid Westland als innovatie voor kostenbeheersing en energieverduurzaming

1.2 Kostenbesparing en verduurzaming glastuinbouw bepalend voor perspectief SGW 6

$\begin{array}{lll}1.3 & \text { Focus op effecten glastuinbouwklanten } & 7\end{array}$

2.1 Beginselen Smart Grid Westland en data-analyse dienen als basis $\quad 8$

2.2 Vraaggesprekken deelnemers bieden een beeld op de praktijk 8

2.3 Beschouwing pilotperiode blijkt mogelijk met data en ervaringen deelnemers 8

2.4 Koppelen van inzichten en toekomstbeeld tot $2030 \quad 9$

3.1 Kosten en duurzaamheidsafwegingen belangrijk voor glastuinbouwbedrijven 10

3.2 Smart Grid Westland draagt bij aan missie Westland Infra 11

3.3 Verbetering kosteneffectiviteit en $\mathrm{CO}_{2}$-emissiereductie glastuinbouw zijn aantoonbaar

3.4 Ontwikkelingen richting 2030 onderbouwen kansen Smart Grid Westland 14

3.5 Opdoen verdere ervaring met Smart Grid Westland is wenselijk 15 



\title{
Samenvatting
}

\section{S.1 Smart Grid Westland biedt perspectief voor kostenbeheersing en verduurzaming}

\begin{abstract}
Smart Grid Westland (SGW) van Westland Infra draagt bij aan de kostenbeheersing en verduurzaming van het energiegebruik van deelnemende glastuinbouwklanten.

Smart Grid Westland is een innovatie van Westland Infra. Het stelt deelnemende klanten in staat om, als het netwerk ruimte biedt, tegen sterk gereduceerde kosten elektrisch vermogen te betrekken. In de pilotperiode van 2019 en 2020 hebben meer dan 30 glastuinbouwbedrijven deelgenomen. Deze glastuinbouwbedrijven deden dit vanuit vier te onderscheiden motieven. De eerste twee motieven hebben te maken met kostenbeheersing bij (1) het vergroten van de belichtingsintensiteit en/of (2) het verlengen van de belichtingsperiode. De andere twee motieven komen voort uit verduurzaming door $\mathrm{CO}_{2}$-emissiereductie doordat SGW glastuinbouwbedrijven helpt bij (3) het verlagen van de vraag naar warmte opgewekt met aardgas of (4) het vervangen van fossiele energievoorzieningen door duurzame bronnen. Deze motieven kunnen in de praktijk ook parallel/overlappend plaatsvinden.
\end{abstract}

Het gebruik van het SGW in de periode van 2019 tot medio 2020 is beperkt geweest. Dit kwam door de gunstige aardgasprijzen voor eigen opwekking van elektriciteit met wkk (sparkspread), de stijging van de Opslag Duurzame Energie (ODE) en de relatieve lange leveringsonderbreking netwerk voor externe $\mathrm{CO}_{2}$ (OCAP). Dit waren externe factoren en niet structureel van aard. Structureel zijn wel de toename van het gebruik van belichting in de glastuinbouw, het verlagen van de warmtevraag en de vervanging van fossiele energiebronnen door energievoorzieningen zonder $\mathrm{CO}_{2}$-emissie (zoals geothermie).

Vanuit deze structurele ontwikkelingen en de aangetoonde bijdrage aan kostenbeheersing en verduurzaming bij deelnemende glastuinbouwklanten heeft SGW een goed toekomstperspectief. Ook draagt SGW bij aan de missie van Westland Infra waarin ontwikkelen, innoveren en samenwerken zijn benoemd om hiermee bij te dragen aan de energietransitie en klantgerichte dienstverlening. Hiernaast verschaft SGW Westland Infra inzicht in de effecten van prijsprikkels op het elektriciteitsgebruik bij glastuinbouwklanten.

\section{S.2 Effecten reiken voorbij de individuele klantrelatie}

Ook buiten de relatie individuele klanten en Westland Infra hebben initiatieven baat bij SGW. Op nationaal niveau draagt het bij aan het verlagen van de $\mathrm{CO}_{2}$-emissie van de glastuinbouw waar door het ministerie van Landbouw, Natuur en Voedselkwaliteit en Glastuinbouw Nederland in het programma Kas als Energiebron aan gewerkt wordt. Regionaal draagt SGW bij aan modernisering en verduurzaming van de glastuinbouw in de gemeenten Westland en Midden-Delfland. Ook helpt het lokale initiatieven van glastuinbouwbedrijven en Warmtesysteem Westland (WSW) om te concurreren met het fossiele alternatief (wkk).

\section{S.3 Data, vraaggesprekken en analyse vormen bouwstenen voor evaluatie}

Wageningen Economic Research is door Westland Infra gevraagd bouwstenen aan te leveren voor hun evaluatie van het SGW op de thema's kosteneffecten en duurzaamheid bij deelnemers. Dit is begonnen met het doorgronden van de beginselen van het SGW-concept, netwerktarieven en gebruikersdata. Hierna zijn vraaggesprekken gevoerd met deelnemende bedrijven. Hierbij is stilgestaan bij hun beoogde insteek, het gebruik in de pilotperiode en hun beeld van toekomstig gebruik. Hierna is met het uitwerken van voorbeelden kwantitatief inzicht verkregen. 


\section{$1 \quad$ Inleiding}

\subsection{Smart Grid Westland als innovatie voor kostenbeheersing en energieverduurzaming}

Grootverbruikers van elektriciteit dragen bij aan de netwerkkosten van energiedistributie door het betalen van netwerkvergoedingen. In het verzorgingsgebied van Westland Infra behoort het grootste deel van deze grootverbruikers tot de glastuinbouwsector. Bij de inspanningen van de glastuinbouw om kosten te beheersen en energieverduurzaming te realiseren, is door glastuinbouwbedrijven en Westland Infra gekeken naar de mogelijkheden die het bestaande elektriciteitsnetwerk hiertoe biedt.

Door Westland Infra en haar glastuinbouwklanten is gezamenlijk de conclusie getrokken dat het mogelijk is om boven-contractueel elektrisch vermogen tegen een gereduceerd tarief aan te bieden aan glastuinbouwklanten als er vrije ruimte is in het netwerk. Deze mogelijkheden komen enerzijds door flexibiliteit in de vermogensvraag van belichtende glastuinbouwbedrijven in combinatie met eigen elektriciteitsproductie met aardgas wkk. Anderzijds zorgen nieuwe communicatietechnieken voor mogelijkheden om de vermogensvraag in het netwerk te monitoren en te reguleren. Hierdoor kunnen bedrijven in de gelegenheid gesteld worden om elektrisch vermogen in perioden met ruimte in het net volledig uit het net te betrekken of in de vraag voorzien door inkoop gecombineerd met eigen opwekking met wkk, waardoor bij glastuinbouwklanten kosten bespaard kunnen worden. Door lagere netwerkkosten verbetert de concurrentiepositie van glastuinbouwbedrijven en wordt het (deels) vervangen van wkk door duurzame(re) warmte in combinatie met inkoop van elektriciteit aantrekkelijker, waardoor concurrentiekracht en duurzaamheid van de glastuinbouwklanten kan verbeteren. Lering van de praktische inzetbaarheid van deze Smart Grid-faciliteiten is voor de brede energietransitie van belang kijkend naar toekomstige bronnen (zoals geothermie en warmte van derden), distributie en samenhang.

In het verzorgingsgebied van Westland Infra is daarom in 2019 het pilotproject 'Smart Grid Westland' (SGW) gestart. Dit project stelt aangemelde deelnemers met een MS/LS (middenspanning/laagspanning) of MS (middenspanning) aansluiting in staat tegen een gereduceerd tarief gebruik te maken van boven-contractueel elektrisch vermogen afkomstig van het openbaar net, als er naar oordeel van Westland Infra ruimte in de totale de netcapaciteit is. Deelnemers kunnen dit doen door elektrisch vermogen op en af te regelen in afstemming met de meting en signalen beschikbaar gesteld door Westland Infra. Voor het boven-contractueel aangewende vermogen worden vervolgens sterk gereduceerde kosten in rekening gebracht voor de maximummaandpiek ( $\mathrm{kW}$ max/maand) en de maximumjaarpiek (kW contract). Hiermee kunnen bedrijven kosten reduceren, wkk-inzet optimaliseren en het gebruik van duurzame warmte vergroten.

\subsection{Kostenbesparing en verduurzaming glastuinbouw bepalend voor perspectief SGW}

Westland Infra heeft voor het implementeren van het SGW gedurende de periode van het pilotproject ontheffing verkregen van de Autoriteit Consument \& Markt (ACM). Naast de eigen evaluatie van het project door Westland Infra en de evaluatie met deelnemers, maakt een evaluatie van het project voor de ACM deel uit van de verstrekte ontheffing. Deze evaluatie kent meerdere onderdelen. Drie belangrijke onderdelen hiervan zijn de ervaringen van deelnemende glastuinbouwbedrijven met het SGW, de bedrijfseconomische effecten voor de glastuinbouw en mogelijkheden voor verduurzaming van het energieverbruik, zowel in de pilot als in de toekomst. 
Het doel van Westland Infra is inzicht verkrijgen in de ervaringen van deelnemers met SGW en de aanknopingspunten die SGW biedt voor kostenvoordelen en energieverduurzaming in de glastuinbouw. Deze inzichten vormen vervolgens bouwstenen voor de evaluatie van SGW die Westland Infra maakt over het perspectief van Smart Grids als extra dienst voor bedrijven die elektriciteit inkopen. Daarom heeft Westland Infra Wageningen Economic Research gevraagd bij te dragen aan de evaluatie aan de hand van drie onderzoeksvragen: (1) Hoe is SGW door deelnemers is beleefd; (2) Wat is het verschil in kosten voor de glastuinbouwbedrijven in de pilotperiode geweest en (3) Welke mogelijkheden biedt SGW in de toekomst om energiekosten te beheersen en bij te dragen aan verduurzaming van het energiegebruik?

\subsection{Focus op effecten glastuinbouwklanten}

Het onderzoek heeft betrekking op de effecten van SGW op het bedrijfseconomisch perspectief en energieverduurzaming van deelnemende glastuinbouwbedrijven in het verzorgingsgebied van Westland Infra.

Aspecten op het gebied van automatisering/ICT, regelgeving, en juridische randvoorwaarden van SGW maken geen onderdeel uit van de te verschaffen inzichten. Dit geldt ook voor duurzaamheidsthema's anders dan energie-gerelateerde, zoals afval, water of gewasbescherming. Ook vallen ervaringen van en effecten bij deelnemers buiten de glastuinbouwsector buiten het bereik dit onderzoek. Zouden niet direct verwante aspecten een relevant onderdeel uitmaken van de input verkregen bij de vraaggesprekken, dan zijn deze wel met Westland Infra gedeeld. In de evaluatie en communicatie van Westland Infra naar derden wordt vermeld op welke onderdelen Wageningen Economic Research een bijdrage heeft geleverd aan het inzicht. 


\section{Werkwijze}

\subsection{Beginselen Smart Grid Westland en data-analyse dienen als basis}

De eerste activiteit bestond uit het doorgronden van de SGW-voorwaarden. Hierna is data van Westland Infra geanalyseerd van inkoophoeveelheden van elektriciteit, gecontracteerd en betrokken elektrisch vermogen en relevante kenmerken van de deelnemende bedrijven aan het SGW. Met behulp van een raamwerk werd inzicht verkregen in 'uitgespaarde' netwerkvergoedingen bij deelnemers voor de pilotperiode. Vervolgens werd het resultaat hiervan gekoppeld aan de kenmerken van deze deelnemende bedrijven. Dit gaf de eerste stap voor het bedrijfseconomisch inzicht en was de basis voor het voeren van vraaggesprekken met deelnemers. De genoemde data werden door Westland Infra voor Wageningen Economic Research vertrouwelijk beschikbaar gesteld bij aanvang van het project.

\subsection{Vraaggesprekken deelnemers bieden een beeld op de praktijk}

De tweede activiteit was het uitvoeren van vraaggesprekken met deelnemers. Bij deze interviews werd ingegaan op de ervaringen van deelnemers met het SGW. Hierbij kwamen aan bod: de motivatie, verwachtingen vooraf, de toepassing, beleving en uitwerking bij het gebruik en ten slotte de gedachten van deelnemers over verbetermogelijkheden en kansen voor SGW in de toekomst. Met behulp van een raamwerk zijn vooraf beoogde 'uitgespaarde' netwerkvergoedingen bij deelnemers en de mogelijkheden voor inzet van duurzame warmte en warmte van derden besproken. Contactgegevens van deelnemende glastuinbouwbedrijven waar interviews werden afgenomen, zijn door Westland Infra aan Wageningen Economic Research verstrekt nadat door Westland Infra bij de deelnemer was nagegaan of zij hieraan wilden meewerken. Er hebben vier vraaggesprekken plaatsgevonden met deelnemers, een vraaggesprek met een intermediair (adviseur energie) voor glastuinbouwbedrijven en een vraaggesprek met een medewerker van Westland Infra betrokken bij het klantcontact rond SGW. De verslagen van de interviews blijven bij Wageningen Economic Research en worden als vertrouwelijk behandeld en zijn niet herleidbaar tot individuen.

\subsection{Beschouwing pilotperiode blijkt mogelijk met data en ervaringen deelnemers}

Met de inzichten uit de vraaggesprekken is een beeld gevormd van (1) het bedrijfseconomisch effect bij de deelnemende glastuinbouwbedrijven en (2) de bijdrage aan de verduurzaming van het energiegebruik van de deelnemende glastuinbouwbedrijven. Dit betreft een overzicht van kostenverschil en een verschil in $\mathrm{CO}_{2}$-emissie van de glastuinbouwbedrijven voortkomend uit de ruimte voor de inzet van duurzame warmtebronnen of warmte van partijen buiten de glastuinbouw. Hierbij is gekeken naar de beoogde resultaten en de resultaten in de pilotperiode. Voor de verandering van de $\mathrm{CO}_{2}$-emissie is uitgegaan van de IPCC-methode. Bij deze methode tellen alle $\mathrm{CO}_{2}$-emissies van de inrichting mee. Emissies van energie die van buiten de inrichting wordt aangekocht, tellen niet mee bij de gebruiker, maar bij de bron. Dit is ook de basis van de afspraken die de glastuinbouwsector heeft met de rijksoverheid in het Convenant $\mathrm{CO}_{2}$ emissieruimte binnen het $\mathrm{CO}_{2}$-sectorsysteem glastuinbouw voor de periode 2013-2020. 


\subsection{Koppelen van inzichten en toekomstbeeld tot 2030}

Vanuit de ervaringen van Westland Infra, de deelnemers en het toekomstbeeld van de deelnemers en Westland Infra en de inzichten uit de studie Kompas op 2030 (Smit en van der Velden, 2018) is een beschouwing gemaakt over wat SGW voor de toekomst kan betekenen voor het verlagen van energiekosten en de energietransitie van de glastuinbouwbedrijven. Hierbij zijn energievraag en energievoorziening van de glastuinbouw aan bod gekomen, met thema's als intensivering, energiebesparing, wkk, inkoop van elektriciteit, gebruik van duurzame warmte en inkoop van warmte. Dit is mede onderbouwd vanuit praktijkcases die de bedrijfseconomische en duurzaamheidsimpact duiden in een reguliere situatie en een situatie met gebruik van SGW. Ten slotte is de samenhang getoond van de bevindingen van de onderdelen data, vraaggesprekken, pilot-beschouwing en de voorbeeldcases 2030. 


\subsection{Kosten en duurzaamheidsafwegingen belangrijk voor glastuinbouwbedrijven}

Voor de glastuinbouw is elektriciteit een belangrijk productiemiddel. Het drijft de mechanieken op de kwekerijen aan en ook de automatisering is ervan afhankelijk. Het grootste deel van het elektriciteitsgebruik zit echter bij het gebruik van groeilicht (Van der Velden en Smit, 2013; Van der Velden en Smit, in voorbereiding). Met groeilicht kunnen glastuinbouwbedrijven de opbrengsten van de teelt bevorderen in perioden dat dit voor de afzet aantrekkelijk is. Hiermee kan geprofiteerd worden van hogere prijzen in de winter of bij geplande orders van klanten.

De glastuinbouw voorziet in haar elektriciteitsbehoefte door inkoop van het openbaar net en door eigen opwekking met aardgasmotoren (wkk). Bedrijven zonder belichting kopen bijna hun gehele vraag in. Bedrijven met belichting voorzien in hun basis-vermogensvraag in de veruit de meeste gevallen met wkk's en kopen de rest in. Deze basis-vermogensvraag is afgestemd op de warmtevraag, want een wkk is in de praktijk enkel rendabel als de warmte die vrijkomt bij de elektriciteitsproductie benut wordt (Smit en van der Velden, 2008). Wat de basis-vermogensbehoefte van bedrijven met belichting is, verschilt per bedrijf en hangt samen met de teelt, de strategie van de ondernemer en de kenmerken van de vestigingslocatie. Als de behoefte aan elektriciteit voor belichting groter is dan de warmtebenutting met de wkk toelaat, koopt het bedrijf het resterende vermogen in. De hoeveelheid en het vermogen van dit deel van de inkoop hangt samen met het geïnstalleerd vermogen, de teeltstrategie ten aanzien van de afzetmarkt en de kosten voor de inkoop. Omdat het geïnstalleerd vermogen van de belichting vaststaat (afhankelijk van areaal en intensiteit belichting), is het aan de ondernemer de kosten voor extra inkoop van elektriciteit af te wegen tegen de beoogde opbrengsten vanuit de productie. Bij deze afweging spelen de netwerkkosten voor elektriciteit een rol. Deze kosten bestaan uit een aantal vaste componenten, transportkosten per eenheid en kosten voor de contractcapaciteit op maand- en jaarbasis.

Als bedrijven voorzien dat productprijzen minder gunstig zijn of worden, zullen zij eerder terughoudend zijn met het inzetten van belichting en het aankopen van elektriciteit. Kijkend naar de gemiddelde gebruikspatronen houdt dit in de praktijk in dat het contractvermogen niet het gehele jaar benut wordt. Door gemiddeld hogere productprijzen in de winter en minder zonlicht zal in de winterperiode het contractvermogen doorgaans wel maximaal benut worden. Het omgekeerde speelt in en rond de zomerperiode.

Deze afweging is het meest complex in de flankmaanden (herfst en lente). In deze maanden zijn er regelmatig gelegenheden voor tuinders in de afzetmarkt om tegen gunstige prijzen hun product (bloem/plant/vrucht/groente/stek) te verkopen en is het niet koud en niet warm waardoor niet vaststaat of bij eigen productie van elektriciteit met wkk de warmte benut kan worden. Het zijn deze momenten dat het voor een glastuinbouwondernemer aantrekkelijk kan zijn niet zelf te produceren met de wkk maar elektriciteit in te kopen. Hiernaast kunnen er perioden zijn waarbij de elektriciteitsprijs op de markt dusdanig laag is dat het inkopen van elektriciteit uit het openbare net aantrekkelijker is dan eigen opwekking met de wkk. In beide gevallen kunnen kosten voor contractcapaciteit (vooral die voor de maandpiek) een drempel zijn om van gunstige productmarkt en/of energiemarkt omstandigheden te profiteren.

Een ontwikkeling die in de Nederlandse glastuinbouw - en zeker in de regio Westland (Smit en van der Velden, 2018) - gaande is, is het vervangen van fossiele energiebronnen (zoals aardgas-wkk) door duurzame warmtebronnen en/of het aankopen van warmte van derden. Voorbeelden van duurzame warmtebronnen zijn aardwarmte en koude-/warmteopslag met een warmtepomp. Voorbeelden van aankoop van warmte van derden zijn het gebruik van industriële restwarmte of warmte van energie- 
centrales. Door het toepassen van duurzame energiebronnen dalen (broeikasgas)emissies met effect op bedrijven, sectorschaal, landelijk en mondiaal niveau en verminderd het gebruik van aardgas.

Omdat deze duurzame warmtebronnen naast warmte geen elektriciteit bieden (zoals wkk), zal er elektriciteit ingekocht moeten worden. Hiermee hebben bedrijven die deze warmtebronnen gebruiken een extra kostenafweging en een duurzaamheidsafweging. De extra kostenafweging is die van eigen opwekking van warmte en elektriciteit met aardgas-wkk versus het gebruiken van duurzame warmte en het inkopen van elektriciteit. De duurzaamheidsafweging zit in het verlagen van de CO2-emissie door het vergroten van het gebruiken van duurzame warmte en het inkopen van elektriciteit ten koste van fossiele bronnen (aardgas-wkk en ketels).

De kostenafweging en de duurzaamheidsafweging zijn met elkaar verbonden. Hoe lager de netwerkkosten voor de inkoop van elektriciteit zijn, des te vaker zullen bedrijven meer opbrengsten genereren, lagere kosten hebben en duurzamer produceren. Hiermee verbetert hun concurrentiepositie en duurzaamheidsprestatie.

\subsection{Smart Grid Westland draagt bij aan missie Westland Infra}

Glastuinbouwbedrijven zijn voor Westland Infra een dominante klantengroep als gekeken wordt naar capaciteitsvraag en hoeveelheden. Dit geldt voor aardgas en elektriciteit. Door gesprekken met klanten heeft Westland Infra inzicht gekregen in de rol die netwerkkosten hebben bij de afwegingen van glastuinbouwbedrijven om elektriciteit in te kopen. Efficiënt gebruik van het elektriciteitsnetwerk kan kostenvoordeel geven bij de klant en bij Westland Infra. Met zo'n mogelijke win-winsituatie heeft Westland Infra nagegaan welke optimaliseringsmogelijkheden er zijn. Dit heeft geleid tot de ontwikkeling van Smart Grid Westland: een concept dat gebruikers van het elektriciteitsnetwerk in staat stelt met automatiseringstechniek gedurende bepaalde perioden elektriciteit in te kopen boven de contractcapaciteit tegen gereduceerde tarieven. De perioden hierbij worden bepaald door de belasting van het elektriciteitsnetwerk. Kortweg is het concept als volgt: is de belasting van het netwerk laag, dan kan tegen gereduceerd tarief boven-contractueel elektrisch vermogen betrokken worden; is de belasting hoog, dan geldt het oorspronkelijke contractvermogen (en gangbare clausules bij overschrijding). Het SGW is beschikbaar voor klanten in de aansluitingsgroepen MS/LS en MS die een deelname-overeenkomst met Westland Infra hebben. Deelnemers aan het SGW krijgen van Westland Infra een online stoplicht-signaal (groen en rood) aangeboden en kunnen met eigen automatisering hun vermogensvraag hierop regelen en bewaken.

Naast voordelen voor de klanten heeft SGW voor Westland Infra ook voordelen. Het ontwikkelen, innoveren en samenwerken met tuinders en toeleveranciers maken onderdeel uit van de missie van Westland Infra. Hiernaast draagt SGW bij aan de energietransitie en innovatieve vormen van dienstverlening die onderdeel uitmaken van de visie die Westland Infra op de toekomst heeft ontwikkeld. Ook verhoogt het de benutting van het door Westland Infra beheerde elektriciteitsnetwerk en ondersteunt het de activiteiten van commerciële partijen. Ten slotte heeft de SGW-pilot aan Westland Infra ook inzicht verschaft in de effecten van prijsprikkels op het elektriciteitsgebruik bij glastuinbouwklanten.

\subsection{Verbetering kosteneffectiviteit en $\mathrm{CO}_{2}$-emissiereductie glastuinbouw zijn aantoonbaar}

Voor glastuinbouwbedrijven heeft het gebruik van het SGW effecten op de kosten. Het heeft effect op de kosten als glastuinbouwbedrijven hun productie willen intensiveren door met meer belichting de opbrengsten $/ \mathrm{m}^{2}$ kas te verhogen. En het heeft effect op de kosten als glastuinbouwbedrijven hun productie willen verduurzamen zonder te het energiegebruik extensiveren door met minder fossiele energie gelijke opbrengsten $/ \mathrm{m}^{2}$ kas te realiseren. 
Vanuit het concept van SGW, de data van 2019/2020 en de vraaggesprekken met deelnemers is een kwalitatief beeld op de bedrijfseconomische effecten en de bijdrage aan $\mathrm{CO}_{2}$-emissiereductie te geven (paragraaf 3.1). Voor een kwantitatief beeld voor 2019/2020 ligt dit lastiger. Dat komt enerzijds doordat de deelnemersgroep lopende het jaar 2019 de SGW technologie is gaan toepassen, er nog kinderziektes in de technologie moesten worden opgelost en doordat motieven niet te labelen zijn aan gebruik. Anderzijds werd het bemoeilijkt door invloeden van buiten zoals buitenklimaat (warme jaren), prijzen aardgas en elektriciteit (en hun verhouding; sparkspread) en leveringsonderbrekingen van OCAP (externe $\mathrm{CO}_{2}$ ). Hierdoor is de populatie onvoldoende representatief en is de data onvoldoende om eenduidig de bijdrage van SGW aan de kostenbeheersing (concurrentiekracht) en verduurzaming ( $\mathrm{CO}_{2}$-emissiereductie) te bepalen.

Echter, met de kwalitatieve beschouwing (concept SGW, data 2019/2020 en vraaggesprekken; paragraaf 3.1), inzichten vanuit onder andere de Energiemonitor van de Glastuinbouw (Van der Velden en Smit, in voorbereiding) en expertise bij Wageningen Economic Research kunnen wel praktijkcases worden gemaakt die wel kwantitatief inzicht geven. Hieronder wordt aan de hand van vier cases van glastuinbouwbedrijven geduid wat de kosteneffecten en de effecten op de $\mathrm{CO}_{2}$-emissie zijn van het gebruik van het SGW. In Bijlage 1 zijn de cijfermatige uitkomsten weergegeven.

\section{Case 1 'Intensievere belichting bij een vruchtgroentebedrijf'}

In deze situatie installeert een glastuinbouwbedrijf van 5 ha $50 \mathrm{~W} / \mathrm{m}^{2}$ extra lampvermogen om het bestaande elektrisch vermogen te vergroten tot $150 \mathrm{~W} / \mathrm{m}^{2}$ en zo in te spelen op een goed afzetperspectief voor het geteelde product. Het bestaande elektrisch vermogen wordt zowel voor als na de installatie voor $50 \mathrm{~W} / \mathrm{m}^{2}$ gevoed door eigen opwekking met wkk. Er wordt 2.000 uur belicht in de wintermaanden november tot en met maart. Hiernaast wordt gedurende 2.000 uur elektriciteit geproduceerd voor verkoop via het openbaar net.

Uit analyse blijkt dat door de verandering op het bedrijf de hoeveelheid ingekochte elektriciteit bijna verdubbeld. De hoeveelheid aardgas die ingekocht wordt, wijzigt niet en ook de hoeveelheid $\mathrm{CO}_{2}-$ emissie blijft onveranderd. Zonder het gebruik van SGW blijken de netwerkkosten voor elektriciteit ruim 50 duizend euro hoger ( $€ 1,00 / \mathrm{m}^{2} /$ jaar), omdat dan wel het reguliere tarief in rekening gebracht zal worden.

\section{Case 2 'Verlengde belichting bij een vruchtgroentebedrijf'}

In deze situatie besluit een glastuinbouwbedrijf van 10 ha de belichtingsperiode van november tot en met maart uit te breiden met de flankmaanden oktober en april. Hierdoor kan het aantal uren dat belicht wordt toenemen van 2.000 naar 2.750 per jaar. De uren dat het bedrijf elektriciteit verkopen kan, nemen in deze case met gelijke mate af. Het vermogen benodigd voor de belichting blijft $100 \mathrm{~W} / \mathrm{m}^{2}$ en wordt ook tijdens het verlengen van de belichtingsperiode voor de helft gevoed door eigen opwekking met wkk.

Uit analyse blijkt dat door de verandering op het bedrijf de hoeveelheid ingekochte elektriciteit met bijna de helft toeneemt. De hoeveelheid aardgas die ingekocht wordt, wijzigt niet en ook de hoeveelheid $\mathrm{CO}_{2}$-emissie blijft onveranderd. Zonder het gebruik van SGW blijken de netwerkkosten elektriciteit ruim 16 duizend euro hoger ( $€ 0,16 / \mathrm{m}^{2} /$ jaar $)$, omdat dan wel het reguliere tarief in rekening gebracht zal worden.

\section{Case 3 'Warmtebesparing en kasklimaatoptimalisering bij een snijbloemenbedrijf'}

In deze situatie belicht een glastuinbouwbedrijf van 2,5 ha gedurende de maanden oktober tot en met maart. Het heeft een wkk in gebruik en deze produceert $40 \mathrm{~W} / \mathrm{m}^{2}$ elektriciteit. Omdat de belichting een elektrisch vermogen van $60 \mathrm{~W} / \mathrm{m}^{2}$ vraagt, wordt het restant $\left(20 \mathrm{~W} / \mathrm{m}^{2}\right)$ ingekocht. Als het bedrijf warmtebesparende en kasklimaat-verbeterende maatregelen neemt, zal het de inzet van wkk moeten beperken, omdat bij productie van elektriciteit ook de geproduceerde warmte benut moet worden. Dit heeft als effect dat het bedrijf in de twee flankmaanden (oktober en april) de benodigde elektriciteit volledig gaat inkopen. Hierdoor daalt het aantal draaiuren van de wkk van 3.200 naar 2.475 uur per jaar. 
Uit analyse blijkt dat door de verandering op het bedrijf de hoeveelheid ingekochte elektriciteit met een derde toeneemt. Door de warmtebesparing, optimalisering en de verschuiving van eigen opwekking met wkk naar inkoop van elektriciteit dalen de hoeveelheid aardgas die ingekocht wordt en de $\mathrm{CO}_{2}$-emissie met ruim $16 \%$. Zonder het gebruik van SGW blijken de netwerkkosten elektriciteit ruim 17 duizend euro hoger ( $€ 0,68 / \mathrm{m}^{2} /$ jaar).

Case 4 'Vervanging warmte uit fossiele bron door warmte-alternatief bij een potplantenbedrijf' In deze situatie belicht een glastuinbouwbedrijf van 7,5 ha gedurende 6 maanden met een elektrisch vermogen $60 \mathrm{~W} / \mathrm{m}^{2}$. Het heeft een wkk in gebruik en deze produceert $40 \mathrm{~W} / \mathrm{m}^{2}$ elektriciteit. Omdat de belichting een elektrisch vermogen van $60 \mathrm{~W} / \mathrm{m}^{2}$ vraagt, wordt het restant $\left(20 \mathrm{~W} / \mathrm{m}^{2}\right)$ ingekocht. Als het bedrijf gebruik gaat maken van geothermie en externe $\mathrm{CO}_{2}$, gaat het de inzet van wkk beperken. Dit is omdat gebruik van de duurzame bron voorrang krijgt en dat bij productie van elektriciteit met wkk ook de geproduceerde warmte benut moet worden. Dit heeft als effect dat het bedrijf in de flankmaanden (oktober en april) alle benodigde elektriciteit volledig gaat inkopen.

Uit analyse blijkt dat door de verandering op het bedrijf de hoeveelheid ingekochte elektriciteit met bijna $45 \%$ toeneemt. Door de inzet van alternatieve warmte en de verschuiving van eigen opwekking met wkk naar inkoop van elektriciteit dalen de hoeveelheid aardgas dat ingekocht wordt en de $\mathrm{CO}_{2}-$ emissie met ruim 40\%. Zonder het gebruik van SGW blijken de netwerkkosten elektriciteit bijna 28 duizend euro hoger ( $€ 0,37 / \mathrm{m}^{2} /$ jaar $)$.

\section{Vrijgave Smart Grid Westland 2019}

In het jaar 2019 was ongeveer $80 \%$ van de tijd het signaal 'vrij', anders gezegd circa 1.750 uur was er geen ruimte om SGW-vermogen te betrekken (Tabel 3.2). Nadere analyse heeft aangetoond dat voor 2019 deze momenten vrij gelijkwaardig over het jaar verdeeld waren.

Voor het gebruik van groeilicht zijn het eerste en laatste kwartaal (oktober-maart) de belangrijkste perioden (minste zonlicht, hogere prijzen voor glastuinbouwproducten). Uit verdere verdieping blijkt dat, als gekeken wordt naar de uren tussen middernacht en 4 uur 's middags, de vrijgave circa $70 \%$ was. Over geheel 2019 bekeken lag de gemiddelde vrijgave hoger dan de vrijgave tijdens de perioden die voor belichtende glastuinbouwbedrijven voornamelijk van belang zijn. Bij voorbeeldsituatie 1 (intensiveren) zou dit betekenen dat circa $30 \%$ van de tijd geen gebruikgemaakt kan worden van vermogen binnen de SGW-voorwaarden.

Inzoomend op de twee middelste kwartalen (april-september) die voor glastuinders met belichting minder belangrijk zijn, blijkt dat in 2019 in deze periode meer dan 80\% vrijgave was. Als gekeken wordt naar de uren tussen middernacht en 10 uur 's ochtends blijkt dat de vrijgave boven de $95 \%$ lag. In deze periode wordt gemiddeld genomen het minst overdag belicht. Dit zou voordelig zijn voor bedrijven vergelijkbaar met de voorbeeldsituaties 2, 3 en 4 (verlengen, besparen en vervangen). Zij zouden in 2019 veel gebruik hebben kunnen maken van de aantrekkelijke SGW-voorwaarden.

Tabel 3.1 Samenvatting signaaldata Smart Grid Westland 2019

\begin{tabular}{lrrrrr} 
Signaal Smart Grid Westland & Totaal & & Q1 en Q4 & & Q2 en Q3 \\
\cline { 3 - 6 } 2019 & alle uren & alle uren & tussen 0:00 en 16:00 & alle uren tussen 0:00 en 16:00 \\
uren periode & 8.751 & 4.363 & 2.957 & 4.389 & 2.558 \\
\hline waarvan 'vrijegave' (groen) & 7.003 & 3.459 & 2.066 & 3.544 & 845 \\
\hline waarvan 'geen vrijgave' (rood) & 1.749 & 904 & 890 & $81 \%$ & 91 \\
\hline aandeel vrijgave & $80 \%$ & $79 \%$ & $70 \%$ & $96 \%$ \\
\hline
\end{tabular}

Bron: Westland Infra.

Op het deel 'SGW-vermogen' hebben de deelnemers geen vermogensgarantie, het vermogen is alleen beschikbaar tijdens 'vrijgave', oftewel ruimte op het net. Dit betekent dat alleen het volume dat binnen SGW-voorwaarden betrokken wordt, beïnvloed wordt. Als de gemiddelde vrijgave van 2019 $(80 \%)$ in beschouwing wordt genomen voor de vier voorbeeldsituaties is het betrokken volume door 
de gebruikers dus hoger dan het aandeel 'vrijgave SGW' (in 2019> 80\%). Bij voorbeeldsituatie 1 had in 2019 94\% van het beoogde, totale elektriciteitsvolume betrokken kunnen worden. Bij voorbeeldsituatie 2, 3 en 4 was dit 97\%, 96\% respectievelijk 96\%. Voor glastuinbouwbedrijven is dit aandeel een belangrijke input voor hun afweging kosten te besparen met SGW of zonder SGW met vaste contractvergoedingen hun vermogen te betrekken. Hiernaast speelt voor hen ook mee hoe de vrijgave verdeeld is over het jaar en per etmaal door de tijden en perioden wanneer belicht wordt.

\subsection{Ontwikkelingen richting 2030 onderbouwen kansen Smart Grid Westland}

\section{Perspectief}

Kijkend naar het perspectief voor deelname in de periode richting 2030 is vooral belangrijk hoe de sectorstructuur (areaal) in de regio Westland zich gaat ontwikkelen en hoe de inzet van groeilicht, warmtebronnen zonder $\mathrm{CO}_{2}$-emissie en wkk op dit areaal zal zijn. In de studie Kompas op 2030 (Smit en van der Velden, 2018) zijn scenario's ontwikkeld. In het scenario van 'gematigde ontwikkeling' komt naar voren dat in de regio Westland de inzet van belichting zal toenemen (areaal en intensiteit), dat gebruik van warmte uit bronnen zonder $\mathrm{CO}_{2}$-emissie sterk zal toenemen, dat wkk-gebruik op bedrijven met belichting zal blijven en dat wkk-gebruik op bedrijven zonder belichting sterk zal afnemen. Gecombineerd met het saldo van intensivering, extensivering en selectieve inzet van energie zal dit leiden tot een lagere vraag naar warmte per $\mathrm{m}^{2}$. Voor het totaal areaal glastuinbouw in de regio Westland werd een daling van de warmtevraag voorzien.

Groei van het areaal met belichting en groei van de intensiteit van belichting en blijvend gebruik van wkk zal betekenen dat de inkoop van elektriciteit zal toenemen. Daling van de warmtevraag per $\mathrm{m}^{2}$ zal leiden tot minder gebruik van wkk en voor belichtende bedrijven meer inkoop. Verdere vervanging van fossiele bronnen door duurzame energiebronnen en warmte aangekocht bij partijen van buiten de sector hebben ook het gevolg dat er meer elektriciteit (en externe $\mathrm{CO}_{2}$ ) ingekocht gaat worden. Dit zijn allemaal signalen van intensivering van de inkoop van elektriciteit. In het gematigde scenario komt deze intensivering overeen met een groei van de elektriciteitsconsumptie van 2,1 naar 2,4 TWh bij een daling van het areaal met $23 \%$. Dit biedt perspectief voor het SGW. Dit wordt onderbouwd vanuit de motieven die deelnemers aangegeven hebben in de vraaggesprekken. Het is eveneens te verwachten dat er in de praktijk combinaties van deelname-motieven zullen zijn. Dit verstevigt de verwachting dat SGW voor meer bedrijven aantrekkelijk zal zijn.

Hiernaast is de verschuiving van aardgas naar een mix van warmtebronnen en inkoop van elektriciteit (duurzamere voorziening) en de selectieve inzet van energie (vraagreductie) in lijn met de insteek van het landelijke transitieprogramma Kas als Energiebron van glastuinbouworganisatie Glastuinbouw Nederland en het ministerie van Landbouw, Natuur en Voedselkwaliteit. Ook ondersteunt SGW regionaal de inspanningen van tuinders, Energie Transitiepartners en de gemeente Westland bij het ontwikkelen en realiseren van een warmtevoorzieningen zonder $\mathrm{CO}_{2}$-emissie.

\section{Obstakels}

Strategisch gezien is er veel perspectief voor het SGW. Er zijn echter ook obstakels. Uit de vraaggesprekken met de deelnemers en Westland Infra blijkt dat deze obstakels vooral buiten de directe invloedsfeer van de deelnemers of de netbeheerder liggen. In de vraaggesprekken zijn hiervan voorbeelden genoemd die het gebruik van het SGW in 2019 parten speelden. Dit waren een onverwachte mutatie van de heffingslasten (sterke stijging ODE), aanhoudend lage aardgasprijzen (ongunstig voor beperken inzet wkk) en onderbreking van de levering van externe $\mathrm{CO}_{2}$ (grootonderhoud bij de bronnen van OCAP).

Er zijn nog andere risico's voor een goed perspectief van het SGW. Denk hierbij aan ongunstige ontwikkelingen op de markt voor tuinbouwproducten. Vooral voor de teelt van sierteeltproducten en producten in het hogere waarde-segment zal dit de inzet van belichting beïnvloeden (intensivering en verlenging). Hierbij kan ook gedacht worden aan het stagneren van de ontwikkeling van duurzame warmtebronnen (zoals geothermie) en het ontsluiten van warmte van derden (zoals restwarmte uit de 
Rijnmond). Stagnatie van het beschikbaar krijgen van alternatieve warmtebronnen zal vervanging van wkk beperken. En ten slotte is het nog niet duidelijk of grootschalige deelname aan het SGW in de perioden dat er ruimte is op het net voor vrije vermogensafname de ruimte voor gebruik van SGW sterk zal beperken.

\subsection{Opdoen verdere ervaring met Smart Grid Westland is wenselijk}

Voor glastuinbouwbedrijven biedt het concept van SGW kansen. Met bestaande voorzieningen en beperkte investering in automatisering kunnen $\mathrm{CO}_{2}$-emissiereductie en/of verbetering van de kosteneffectiviteit gerealiseerd worden. Voor Westland Infra is SGW een innovatie die past bij de visie en missie. Hiernaast heeft de pilot bijgedragen aan inzichten rondom prijsprikkels en verbetert het de randvoorwaarden waarbinnen energietransitie in de glastuinbouw gerealiseerd kan worden.

Dit laatste is zeker ook buiten de relatie tussen netwerkbeheerder en afnemer relevant. Het SGW ondersteunt namelijk doelen van de gemeenten Westland en Midden-Delfland en het transitieprogramma Kas als Energiebron (ministerie LNV en Glastuinbouw Nederland). En het concept ondersteunt bovendien duurzame energieprojecten alwaar flexibiliteit kan leiden tot betere resultaten.

Naast aantoonbare ondersteuning van de doelen en missie van klanten, Westland Infra en partners heeft de pilot in 2019 en 2020 echter niet het beoogde resultaat gegeven. Het gebruik van SGW is in die periode sterk beïnvloed door externe factoren. Invloeden van buiten waren de verhoging van de Opslag Duurzame Energie, de relatief gunstige verhouding tussen de aardgasprijs en elektriciteitsprijs (sparkspread) en relatief meer leveringsonderbrekingen bij OCAP (externe $\mathrm{CO}_{2}$ voor gewasgroei). Deze factoren maakten het minder aantrekkelijk elektriciteit in te kopen en aantrekkelijker elektriciteit te produceren met eigen gasmotoren.

Dit zijn echter tijdelijke gebeurtenissen. De glastuinbouw en haar partners zijn structureel gericht op een reductie van de $\mathrm{CO}_{2}$-emissie door inzet van duurzame energie, energiebesparing en verschuiving van fossiel naar duurzaam en inkoop van derden. Hierdoor zal inkoop van elektriciteit in de toekomst belangrijker worden. Dit wordt ook nog eens versterkt door de ontwikkeling van selectiever verwarmen en intensiever belichten (Van der Velden en Smit, 2020). Het is vanwege deze incidentele ontwikkeling-en en de structurele transitie goed verdere ervaring op te doen met SGW. Enerzijds omdat de nadelige effecten van de tariefsverhoging van de ODE nog geëvalueerd worden, duurzame warmte (Trias) verder wordt uitgerold en er doorlopend gewerkt wordt aan betere beschikbaarheid van externe $\mathrm{CO}_{2}$. Anderzijds omdat de vestiging van moderne, marktgerichte en duurzame glastuinbouw in de regio Westland stimuleert. Ook is het belangrijk inzicht te krijgen in de beschikbaarheid van SGW-voorwaarden (vrijgave/groen) als het breder en intensiever gebruikt gaat worden.

Het nagaan wat de effecten op de ruimte in het netwerk is bij een opgeschaald gebruik is aan te bevelen, zeker in relatie tot het kostenvoordeel en verduurzamingsperspectief. 


\section{$4 \quad$ Conclusie}

\section{Conclusies}

De motieven van glastuinbouwbedrijven voor deelname aan Smart Grid Westland zitten in kosteneffectiviteit bij het vergroten van de belichtingsintensiteit of verlengen van de belichtingsperiode enerzijds. En bij het doorvoeren van energiebesparingsstrategieën of het vervangen van fossiele energievoorzieningen (wkk) anderzijds.

De innovatie Smart Grid Westland en het aanbieden van de diensten verbonden aan Smart Grid Westland ondersteunen de missie van Westland Infra door bij te dragen aan de energietransitie in het verzorgingsgebied.

Het toekomstperspectief voor Smart Grid Westland is positief, omdat het bijdraagt aan het beheersen van kosten bij deelnemers waarbij energiekosten een belangrijk aandeel hebben in de totale kosten. En omdat het de ingezette energietransitie van de glastuinbouw van fossiel naar duurzaam, als een van de belangrijkste duurzaamheidsthema's, ondersteunt.

Vanuit vier uitgewerkte cases is door het gebruik van SGW een kostenbesparing te schatten van $€ 0,16$ tot $€ 1,00$ per $\mathrm{m}^{2}$ kas. De mate van besparing hangt hierbij samen met de acties die bij deze cases doorgevoerd worden om hun productie te intensiveren of te verduurzamen. Als meerdere acties worden uitgevoerd kan de kosteneffectiviteit verder toenemen doordat effecten cumulatief zijn.

Een reductie van de $\mathrm{CO}_{2}$-emissie bij deelnemers die inspanningen verrichten om hun warmtevraag te verlagen of energievoorzieningen zonder $\mathrm{CO}_{2}$-emissie in gebruik nemen is afhankelijk van bedrijfskenmerken in te schatten op maximaal 10 tot $30 \mathrm{~kg}$ per $\mathrm{m}^{2}$ kas.

Analyse van de data van pilot toont aan dat het gebruik van SGW en daarmee de kostenbesparing en emissiereductie in 2019 en 2020 aanzienlijk lager lag dan beoogd door de deelnemers en Westland Infra. Deelnemers bevestigen dit vanuit hun praktijk. Oorzaken hiervan zijn de verhoogde ODE, de sparkspread die voor eigen elektriciteitsopwekking met wkk gunstig was en de leveringsonderbreking van OCAP (externe $\mathrm{CO}_{2}$ ).

De belemmeringen in 2019 en 2020 die gebruik van het Smart Grid Westland tegenwerkten zijn extern en niet het gevolg van acties van deelnemers, Westland Infra of partners. De motieven en het perspectief voor Smart Grid Westland zijn wel te verbinden aan het streven van deelnemers, Westland Infra en hun partners. Deze motieven zijn structureel.

\section{Aanbeveling}

Omdat incidentele gebeurtenissen en marktsituaties de inzet van Smart Grid Westland belemmerd hebben en inzicht in de mogelijkheden bij een grotere groep deelnemers nog niet voorhanden is, is het aan te bevelen om verdere ervaring met SGW op te doen. 


\section{Literatuur, websites en bronnen}

\section{Literatuur}

N. van der Velden en P. Smit, Energiemonitor van de Nederlandse glastuinbouw 2019, in voorbereiding, Wageningen Economic Research, Den Haag

N. van der Velden en P. Smit, Protocol energiemonitor van de Nederlandse glastuinbouw, in voorbereiding, Wageningen Economic Research, Den Haag

P. Smit en N. van der Velden, Groei elektriciteitsconsumptie glastuinbouw: Hoe verder?, 2013, Landbouw Economisch Instituut (Wageningen Economic Research), Den Haag

P. Smit en N. van der Velden, Kompas op 2030; Verduurzamingsrichtingen energievoorziening Westlandse glastuinbouw 2018, Wageningen Economic Research, Den Haag

N. van der Velden, P. Smit en R. van der Meer, Tariefstijging ODE inkoop elektriciteit: effecten op kosten en $\mathrm{CO}_{2}$-emissie glastuinbouw, in voorbereiding, Wageningen Economic Research, Den Haag

\section{Websites}

www.westlandinfra.nl (Smart Grid Westland en tarieven MS en MS/LS)

\section{Geraadpleegde deskundigen}

2 medewerkers Westland Infra

1 dienstverlener energie-advies

5 deelnemers Smart Grid Westland 


\section{Bijlage 1 Uitwerking motieven}

Tabel B.1 Cijfermatige uitwerking cases inzet Smart Grid Westland vanuit vier motieven

\begin{tabular}{|c|c|c|c|c|c|c|c|c|c|c|c|c|c|}
\hline \multicolumn{2}{|l|}{ Voorbeeldcases } & \multicolumn{3}{|c|}{ 1: 'Intensivere belichting' } & \multicolumn{3}{|c|}{ 2: 'Verlengende belichting' } & \multicolumn{3}{|c|}{ 3: 'Warmte besparen' } & \multicolumn{3}{|c|}{ 4: 'Vervangen aardgas' } \\
\hline Areaal & $\mathrm{m}^{2}$ & 50.000 & 50.000 & 50.000 & 100.000 & 100.000 & 100.000 & 25.000 & 25.000 & 25.000 & 75.000 & 75.000 & 75.000 \\
\hline Warmteconsumptie & $\mathrm{kWh} / \mathrm{y}$ & 15.625 .000 & 15.625 .000 & 15.625 .000 & 31.250 .000 & 31.250 .000 & 31.250 .000 & 5.500 .000 & 4.812 .500 & 4.812 .500 & 16.500 .000 & 16.500 .000 & 16.500 .000 \\
\hline Elektriciteitsconsumptie & $\mathrm{kWh} / \mathrm{y}$ & 10.400 .000 & 15.400 .000 & 15.400 .000 & 20.700 .000 & 28.200 .000 & 28.200 .000 & 3.450 .000 & 3.450 .000 & 3.450 .000 & 9.400 .000 & 9.400 .000 & 9.400 .000 \\
\hline Vermogen wkk (elektrisch) & $\mathrm{kW}$ & 2.500 & 2.500 & 2.500 & 5.000 & 5.000 & 5.000 & 1.000 & 1.000 & 1.000 & 3.000 & 3.000 & 3.000 \\
\hline Elektriciteitsproductie wkk (consumptie) & $\mathrm{kWh} / \mathrm{y}$ & 5.000 .000 & 5.000 .000 & 5.000 .000 & 10.000 .000 & 13.750 .000 & 13.750 .000 & 2.200 .000 & 1.475 .000 & 1.475 .000 & 6.000 .000 & 4.500 .000 & 4.500 .000 \\
\hline Elektriciteitsproductie wkk (verkoop) & $\mathrm{kWh} / \mathrm{y}$ & 5.000 .000 & 5.000 .000 & 5.000 .000 & 10.000 .000 & 6.250 .000 & 6.250 .000 & 1.000 .000 & 1.000 .000 & 1.000 .000 & 3.000 .000 & 1.500 .000 & 1.500 .000 \\
\hline Warmteproductie wkk (consumptie) & $\mathrm{kWh} / \mathrm{y}$ & 12.500 .000 & 12.500 .000 & 12.500 .000 & 25.000 .000 & 25.000 .000 & 25.000 .000 & 4.000 .000 & 3.093 .750 & 3.093 .750 & 11.250 .000 & 7.500 .000 & 7.500 .000 \\
\hline Consumptie aardgas wkk & $\mathrm{m} 3 / \mathrm{y}$ & 2.843 .332 & 2.843 .332 & 2.843 .332 & 5.686 .665 & 5.686 .665 & 5.686 .665 & 909.866 & 703.725 & 703.725 & 2.558 .999 & 1.705 .999 & 1.705 .999 \\
\hline Consumptie alternatieve warmte & $\mathrm{GJ} / \mathrm{y}$ & 0 & 0 & 0 & 0 & 0 & 0 & 0 & 0 & 0 & 0 & 27.000 & 27.000 \\
\hline Consumptie aardgas ketel & $\mathrm{m}^{3} / \mathrm{y}$ & 71.083 & 71.083 & 71.083 & 710.833 & 710.833 & 710.833 & 170.600 & 195.479 & 195.479 & 597.100 & 170.600 & 170.600 \\
\hline Vermogen elektriciteit inkoop (vast) & kW & 2.700 & 5.200 & 2.700 & 5.350 & 5.350 & 5.350 & 575 & 1.575 & 575 & 1.700 & 3.200 & 1.700 \\
\hline Vermogen elektriciteit inkoop (SGW) & $\mathrm{kW}$ & 0 & 0 & 2.500 & 0 & 0 & 0 & 0 & 0 & 1.000 & 0 & 0 & 1.500 \\
\hline Vermogen elektriciteit inkoop (totaal) & kW & 2.700 & 5.200 & 5.200 & 5.350 & 5.350 & 5.350 & 575 & 1.575 & 1.575 & 1.700 & 3.200 & 3.200 \\
\hline Volume elektriciteit inkoop & $\mathrm{kWh} / \mathrm{y}$ & 5.400 .000 & 10.400 .000 & 10.400 .000 & 10.700 .000 & 14.450 .000 & 14.450 .000 & 1.250 .000 & 1.975 .000 & 1.975 .000 & 3.400 .000 & 4.900 .000 & 4.900 .000 \\
\hline Volume elektriciteit verkoop & $\mathrm{kWh} / \mathrm{y}$ & 5.000 .000 & 5.000 .000 & 5.000 .000 & 10.000 .000 & 6.250 .000 & 6.250 .000 & 1.000 .000 & 1.000 .000 & 1.000 .000 & 3.000 .000 & 1.500 .000 & 1.500 .000 \\
\hline Maanden max vermogen (vast) & $\mathrm{m} / \mathrm{y}$ & 5 & 5 & 5 & 5 & 7 & 5 & 6 & 2 & 4 & 6 & 2 & 4 \\
\hline Maanden max vermogen (SGW) & $\mathrm{m} / \mathrm{y}$ & 0 & 0 & 0 & 0 & 0 & 2 & 0 & 0 & 2 & 0 & 0 & 2 \\
\hline Volume gas (totaal) & $\mathrm{m}^{3} / \mathrm{y}$ & 2.914 .416 & 2.914 .416 & 2.914 .416 & 6.397 .498 & 6.397 .498 & 6.397 .498 & 1.080 .466 & 899.204 & 899.204 & 3.156 .099 & 1.876 .599 & 1.876 .599 \\
\hline Vermogen elektriciteit inkoop (jaar) & kW & 2.700 & 5.200 & 2.700 & 5.350 & 5.350 & 5.350 & 575 & 1.575 & 575 & 1.700 & 3.200 & 1.700 \\
\hline Vermogen elektrictieit inkoop (maand) & $\mathrm{kW}$ & 1.125 & 2.167 & 1.125 & 2.229 & 3.121 & 2.229 & 325 & 492 & 242 & 950 & 1.200 & 700 \\
\hline $\mathrm{CO}_{2}$-emissie (IPCC) & $\mathrm{kg}$ & 5.210 .975 & 5.210 .975 & 5.210 .975 & 11.438 .726 & 11.438 .726 & 11.438 .726 & 1.931 .874 & 1.607 .777 & 1.607 .777 & 5.643 .105 & 3.355 .360 & 3.355 .360 \\
\hline Kosten netwerk vermogen (max) & $€ / y$ & 33.696 & 64.896 & 33.696 & 66.768 & 66.768 & 66.768 & 7.176 & 19.656 & 7.176 & 21.216 & 39.936 & 21.216 \\
\hline Kosten netwerk vermogen (mnd) & $€ / y$ & 20.520 & 39.520 & 20.520 & 40.660 & 56.924 & 40.660 & 5.928 & 8.968 & 4.408 & 17.328 & 21.888 & 12.768 \\
\hline Kosten netwerk vermogen (totaal) & $€ / y$ & 54.216 & 104.416 & 54.216 & 107.428 & 123.692 & 107.428 & 13.104 & 28.624 & 11.584 & 38.544 & 61.824 & 33.984 \\
\hline
\end{tabular}

1) Voor de berekening van de netwerkkosten capaciteit is het verzorgingsgebied van Westland Infra en de categorie MS aangehouden. Het tarief voor de jaarcontractwaarde is $€ 12,48 / \mathrm{kW}$ en die voor de maandcontractwaarde $€ 1,52 / \mathrm{kW}$.

2) Onderste verbrandingswaarde van $1 \mathrm{~m}^{3}$ aardgas is gesteld op 8,79 kWh per $\mathrm{m}^{3}$. Verbranding in een ketel geeft $8,79 \mathrm{kWh}$ warmte, gebruik in een wkk geeft 4,40 kWh warmte en $3,52 \mathrm{kWh}$ elektriciteit.

3) De $\mathrm{CO}_{2}$-emissie is bepaald volgens de IPCC-methode. Voor de emissiefactor is $1,788 \mathrm{~kg} \mathrm{CO}_{2}$ per $\mathrm{m}^{3}$ aardgas aangehouden (RVO, 2019).

4) In 2019 bedroeg het aandeel 'vrijgave/groen' gemiddeld circa $80 \%$ van de tijd. 
Wageningen Economic Research Postbus 29703

2502 LS Den Haag

T 0703358330

Ecommunications.ssg@wur.nl

www.wur.nl/economic-research

Wageningen Economic Research NOTA 2020-076
De missie van Wageningen University \& Research is 'To explore the potential of nature to improve the quality of life'. Binnen Wageningen University \& Research bundelen Wageningen University en gespecialiseerde onderzoeksinstituten van Stichting Wageningen Research hun krachten om bij te dragen aan de oplossing van belangrijke vragen in het domein van gezonde voeding en leefomgeving. Met ongeveer 30 vestigingen, 6.500 medewerkers ( $5.500 \mathrm{fte}$ ) en 12.500 studenten behoort Wageningen University \& Research wereldwijd tot de aansprekende kennisinstellingen binnen haar domein. De integrale benadering van de vraagstukken en de samenwerking tussen verschillende disciplines vormen het hart van de unieke Wageningen aanpak. 



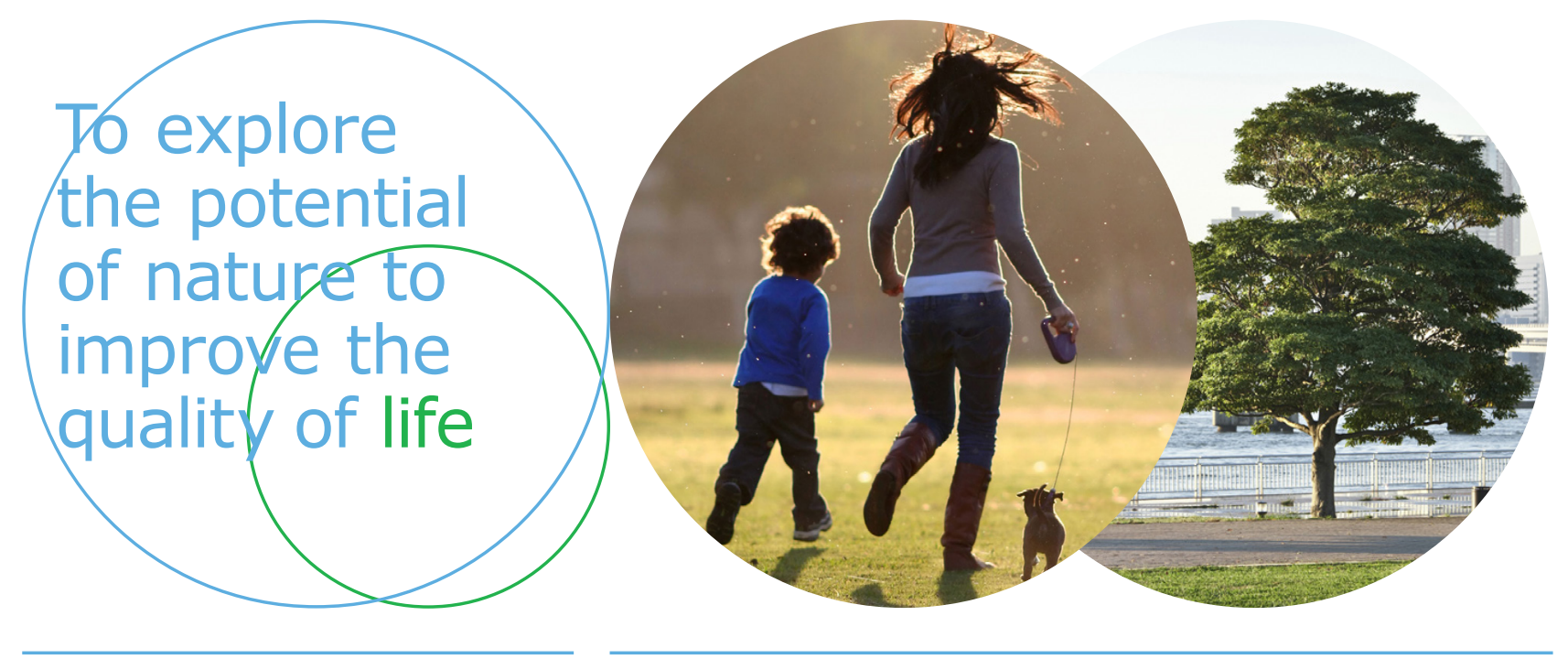

Wageningen Economic Research Postbus 29703

2502 LS Den Haag

T 0703358330

E communications.ssg@wur.nl www.wur.nl/economic-research

Nota 2020-076
De missie van Wageningen University \& Research is 'To explore the potential of nature to improve the quality of life'. Binnen Wageningen University \& Research bundelen Wageningen University en gespecialiseerde onderzoeksinstituten van Stichting Wageningen Research hun krachten om bij te dragen aan de oplossing van belangrijke vragen in het domein van gezonde voeding en leefomgeving. Met ongeveer 30 vestigingen, 6.500 medewerkers ( $5.500 \mathrm{fte}$ ) en 12.500 studenten behoort Wageningen University \& Research wereldwijd tot de aansprekende kennisinstellingen binnen haar domein. De integrale benadering van de vraagstukken en de samenwerking tussen verschillende disciplines vormen het hart van de unieke Wageningen aanpak. 